\title{
Influence of Dietary Protein Level and Source on the Course of Protein Digestion Along the Small Intestine of the Veal Calf
}

\author{
L. Montagne, ${ }^{\star}$ I. Crévieu-Gabriel,† R. Toullec, ${ }^{\star}$ and J. P. Lallès* \\ *Unité Mixte de Recherches sur le Veau et le Porc, \\ Institut National de la Recherche Agronomique, \\ Ecole Nationale Supérieure Agronomique de Rennes, 65 rue de Saint Brieuc, CS 84215, \\ 35042 Rennes Cedex, France \\ †Station de Recherches Avicoles, \\ Institut National de la Recherche Agronomique Nouzilly, \\ 37380 Monnaie, France
}

\begin{abstract}
The objective of this study was to examine the effect of the dietary crude protein (CP) content and source on the distribution of digesta proteins and peptides according to their molecular mass along the small intestine of veal calves. Diets contained 14, 104, 205, and $279 \mathrm{~g} / \mathrm{kg}$ of CP supplied by skim milk powder (SMP) in experiment 1. Diets contained only SMP or SMP plus proteins (1:1 on digestible CP basis) from either a soybean protein concentrate (SPC), an isolated soy protein partially hydrolyzed (HSPI), or a potato protein concentrate (PPC) in experiment 2. Duodenal, jejunal, and ileal digesta were collected from calves fitted with simple cannulae and continuously infused the milk replacers into the abomasum. The distribution of molecular mass $\left(M_{r}\right)$ of proteins and peptides was studied by gel filtration chromatography. Increasing the dietary $\mathrm{CP}$ level of milk replacers increased the flow of oligopeptides and free amino acids in ileal digesta. Incorporating plant protein increased the flow of proteins with $M_{r}>$ 20,000 in the duodenum and that of proteins and peptides with $M_{r}<10,000$ in the ileum. Hydrolysis of oligopeptides and absorption may be a limiting step in the digestion of plant protein in the veal calf.
\end{abstract}

(Key words: calf nutrition, protein digestion, protein and peptide fractions)

Abbreviation key: HSPI = partially hydrolyzed soybean protein isolate, $\boldsymbol{M}_{\mathbf{r}}=$ molecular mass, $\mathbf{P P C}=$ potato protein concentrate, SMP = skim milk powder, SPC $=$ soybean protein concentrate.

\section{INTRODUCTION}

Skim milk powder (SMP) is increasingly being replaced by plant protein sources, including soybean,

Received July 12, 2002.

Accepted September 12, 2002.

Corresponding author: L. Montagne; e-mail: montagne@roazhon. inra.fr. wheat, pea, corn, lupin, and potato in milk substitutes for veal calves in Europe (Toullec and Lallès, 1995). However, this often leads to decreased apparent digestibility of protein and impaired calf performance (Lallès, 1993). The cause seems to be multifactorial. It could result from a lower intrinsic digestibility of plant proteins, due to their resistance to hydrolysis (Nielsen et al., 1988), and/or to higher losses of endogenous protein (Bush et al., 1992; Lallès et al., 1996). Moreover, plant storage proteins, as well as other components including antinutritional factors (antigenic proteins, tannins, lectins, etc.), may interact with the gut and modify the enzymatic digestion and/or absorptive capacity of the mucosa (Montagne et al., 1999). Thus, intestinal breakdown of proteins and peptides, and absorption of triand di-peptides and AA, may be additional factors limiting digestion of plant protein. This hypothesis is supported by the fact that most nitrogenous compounds including dietary and endogenous fractions present in the lumen of the small intestine consist of peptides and free AA. As an example, 19 to $27 \%$ of nitrogenous compounds of ileal digesta of pigs fed hydrolyzed casein had a molecular mass $\left(\boldsymbol{M}_{\mathbf{r}}\right)<10,000$ (Asche et al., 1989; Leterme et al., 1996). In chickens fed pea flour, 16 to $20 \%$ of these compounds had a $M_{r}<500$ (Crévieu et al., 1997a).

Improving digestive utilization of plant protein in diets for veal calves helps to improve knowledge of the biochemical process of the digestion in the small intestine. There are, to our knowledge, no data for calves comparable to those for pigs and chickens. The aims of this study were, therefore, to examine the progress of digestion and absorption along the small intestine of veal calves by measuring the $M_{r}$ profiles of proteins and peptides in digesta. Calves were fed diets based on SMP and differing by their $\mathrm{CP}$ content in experiment 1 , or diets differing in the protein source (SMP, unhydrolyzed or partially hydrolyzed soybean and potato) in experiment 2. 
Table 1. Ingredient and chemical composition of experimental diets.

\begin{tabular}{|c|c|c|c|c|c|c|c|c|}
\hline & \multicolumn{4}{|c|}{ Diets of experiment $1^{1}$} & \multicolumn{4}{|c|}{ Diets of experiment $2^{2}$} \\
\hline & 14 & 104 & 205 & 279 & Control & $\mathrm{SPC}$ & HSPI & $\mathrm{PPC}$ \\
\hline \multicolumn{9}{|c|}{ Diet ingredient ( $\mathrm{g} / \mathrm{kg}$ reconstituted milk) } \\
\hline $\begin{array}{l}\text { Skim milk product } \\
\text { SPC }^{2}\end{array}$ & 0 & 38.8 & 82.9 & 115.5 & 82.9 & $\begin{array}{l}33.2 \\
41.5\end{array}$ & 33.2 & 33.2 \\
\hline $\mathrm{HSPI}^{2}$ & & & & & & & 20.7 & \\
\hline $\mathrm{PPC}^{2}$ & & & & & & & & 22.0 \\
\hline Lactose & 88.7 & 61.6 & 20.8 & 0 & 15.9 & 24.2 & 45.0 & 43.6 \\
\hline Milk cream ${ }^{3}$ & 80.6 & 80.6 & 80.6 & 80.6 & 80.6 & 80.6 & 80.6 & 80.6 \\
\hline Sodium citrate dihydrate & 2.1 & 2.1 & 2.1 & 2.1 & 2.1 & 2.1 & 2.1 & 2.1 \\
\hline Vitamins and mineral mix ${ }^{4}$ & 28.9 & 17.2 & 13.9 & 2.1 & 18.8 & 18.8 & 18.8 & 18.8 \\
\hline Cr-EDTA solution ${ }^{5}$ & 10.0 & 10.0 & 10.0 & 10.0 & 10.0 & 10.0 & 10.0 & 10.0 \\
\hline \multicolumn{9}{|c|}{ Chemical composition (g/kg DM) } \\
\hline $\mathrm{CP}(\mathrm{N} \times 6.25)^{6}$ & 14 & 104 & 205 & 279 & 214 & 276 & 213 & 206 \\
\hline Fat $^{7}$ & 200 & 200 & 200 & 200 & 200 & 200 & 200 & 200 \\
\hline Ash & 55 & 55 & 68 & 74 & 70 & 78 & 68 & 63 \\
\hline
\end{tabular}

${ }^{1}$ Crude protein level in $\mathrm{g} / \mathrm{kg} \mathrm{DM}$.

${ }^{2}$ SPC: diet containing soybean protein concentrate, HSPI: diet containing hydrolyzed soybean proteins isolate, PPC: diet containing potato protein concentrate.

${ }^{3}$ UHT-treated liquid cream containing $350 \mathrm{~g}$ of fat per $\mathrm{kg}$ maintained in emulsification by $1.8 \mathrm{~g} / \mathrm{kg}$ of emulsifier (soy modified lecithin VP695 supplied by Lucas-Meyer, Hamburg, Germany).

${ }^{4}$ Vitamins and minerals mix were supplied by Celtic-Langlois, Rennes, France. There were formulated in order to have a constant concentration of each mineral and vitamin in the four experimental diets.

${ }^{5} 1.5 \mathrm{mg} \mathrm{Cr} / \mathrm{ml}$. Cr was used as an indigestible marker of the liquid phase of digesta.

${ }^{6}$ Higher in diet SPC than other diets of experiment 2 (see Diets section).

${ }^{7}$ Calculated data.

\section{MATERIALS AND METHODS}

\section{Diets}

The composition of the diets was described previously (Montagne et al., 2000a) and summarized in Table 1. Briefly, in experiment 1, a diet with extremely low level of protein $(14 \mathrm{~g} \mathrm{CP} / \mathrm{kg} \mathrm{DM}$, called protein-free diet in the rest of the text) and three diets based on SMP containing 104, 205 and $279 \mathrm{~g} \mathrm{CP} / \mathrm{kg} \mathrm{DM}$ were formulated. In experiment 2 , four experimental diets differing in the source of protein were formulated, with the control diet based on SMP. The soybean protein concentrate (SPC, Danproveal, Central Soya, Aarhus, Denmark) had been treated with hot aqueous ethanol in order to remove sucrose and $\alpha$-galactosides and to reduce antigenicity. The partially hydrolyzed soybean protein isolate (HSPI, Nurish 1500 from Protein Technologies International, St. Louis, MO) was also hypoantigenic. The potato protein concentrate (PPC, Lysamine, Roquette, Lestrem, France) was obtained by thermocoagulation. The three plant protein-containing diets contained a mixture of SMP and plant products (1:1, on a digestible CP basis), except the SPC diet for which this ratio was lower (2:3) due to an error in SPC mixing. As previously reported (Montagne et al., 2000a), all these products were virtually devoid of antinutritional factors and proved to be well digested by calves (Lallès et al., 1996). All the eight diets were balanced for digestible energy (5 Mcal/kg DM) using lactose. Different mixes that took into account the contribution of the protein sources for vitamins and minerals were formulated in order to have a constant level of vitamins and minerals in all the diets. The level of feed intake was fixed at $55 \mathrm{~g} \mathrm{DM} / \mathrm{kg}$ of $\mathrm{BW}^{0.75} / \mathrm{d}$ ), which is close to the level ( $57 \mathrm{~g} \mathrm{DM} / \mathrm{kg}$ of $\left.\mathrm{BW}^{0.75} / \mathrm{d}\right)$ that would allow a daily BW gain superior to $1000 \mathrm{~g}$ in (nonfistulated) veal calves (Lallès et al., 1995). Individual amounts of feed intake were adjusted weekly to animal BW. Chromium (Cr)-EDTA was used as a liquid phase marker and added to the reconstituted milk (Lallès and Poncet, 1990). Sodium citrate was introduced into the diets in order to prevent clotting in the abomasum, as an attempt to get a regular abomasal emptying for protein and fat, comparable between the diets based on SMP only and those containing plant protein sources, that do not coagulate in the abomasum of the calf (Toullec et al., 1974). Clotting prevention is considered only to affect nutrient flow and not nutrient digestibility or performance in calves aged one month or more (Longenbach and Heinrichs, 1998), as those used in the present study.

Between two successive experimental periods, calves were bucket-fed twice daily a commercial diet (Sofivo, Condé-sur-Vire, France) based on skim milk powder for $5 \mathrm{~d}$ at a level of intake of $55 \mathrm{~g} \mathrm{DM} / \mathrm{kg}$ of $\mathrm{BW}^{0.75} / \mathrm{d}$. 


\section{Animals}

The experiments were conducted under the guidelines of the French Ministry of Agriculture for animal research. Briefly, Holstein male calves were obtained at $2 \mathrm{~d}$ of age from the experimental dairy herd of INRA Rennes, France. They were kept on straw in individual pens (1.5 $\times 2 \mathrm{~m}$ ) throughout the experiment. At 65 to $75 \mathrm{~kg}$ of BW (approximately $6 \mathrm{wk}$ of age), the calves were fitted with a catheter placed at the limit between the fundic and antral regions of the abomasum, $(20$ to $30 \mathrm{~cm}$ from the pylorus), and T-piece cannulae in the proximal duodenum (immediately below the pancreatic duct), midjejunum, and terminal ileum (Montagne et al., 2000a). The calves were then allowed to recover from surgery for 2 wk. After the end of the experiments, the calves were euthanized and the actual location of the cannulae was measured. They were positioned on the duodenum and the ileum at $3 \pm 0.2$ and $99 \pm 0.1 \%$ of the length of the small intestine, respectively (means \pm SEM for all the calves of the two experiments). The jejunal cannula was positioned at $40 \pm 15$ and $54 \pm 4 \%$, in experiments 1 and 2 , respectively.

\section{Experimental Design}

Experiment 1 was carried out on six calves that received each of the four diets (the protein free diet and the three diets based on different levels of SMP) at random. Each diet was tested during an experimental period lasting $9 \mathrm{~d}$. During the experimental periods, the milk was infused continuously through the abomasal catheter, using a peristaltic pump (Masterflex, Cole-Parmer Instrument Co., Vernon Hills, IL), in order to reach a steady state for digestion process and digesta flow along the small intestine. The infusion rate comprised between 6 and $10 \mathrm{~g} / \mathrm{min}$, depending on the BW of the calves. In a previous study in which the SMP-based milk replacer was continuously infused in the duodenum to reach such a steady state, we found satisfactory fecal digestibility data of 0.95 and 0.91 for organic matter and $\mathrm{N}$, respectively, with calves aged 5 to 6 wk (Lallès and Poncet, 1990). Between two experimental periods (5 d), the calves were bucket fed a commercial diet.

Experiment 2 was carried out on 10 calves, different than those used in experiment 1 . The design of experiment 2 was similar to that of experiment 1 . However, abomasal infusion of HSPI, and to a lesser extent SPC, generated successive episodes of constipation and diarrhea, thus preventing the calves from completing the experimental design. Therefore, SPC, HSPI, and PPC diets were tested separately on 5,3 , and 8 different calves, respectively, that also received the control diet randomly. Therefore experiment 2 was analyzed as three independent trials, each involving the comparison of data between a diet containing a plant protein source and the respective control diet based on SMP only.

Ileal, jejunal and duodenal digesta were collected on d 6, 7, and 8, respectively, after the beginning of diet infusion. Approximately $150 \mathrm{~g}$ of digesta, were sampled five times a day at $0800,1200,1600,2000$, and $2400 \mathrm{~h}$ at each anatomical site, representing altogether approximately $6.5 \%$ of milk replacer intake. A mixture of preservatives [15 $\mathrm{m} M$ EDTA, $1 \mathrm{~m} M$ sodium azide, $2 \mathrm{~m} M$ phenylmethylsulfonyl fluoride] was then added to the digesta in order to limit enzymatic and bacterial activities. The samples were vigorously shaken and frozen at $-20^{\circ} \mathrm{C}$ prior to freeze-drying. Afterwards, representative average samples were prepared per experimental diet and intestinal site for this fractionation study. Aliquots of these representative samples at the duodenum were also filtered (mesh size $500 \mu \mathrm{m}$ ) in order to estimate the contribution of straw particles. This was found to be negligible $(<2 \% \mathrm{DM})$, suggesting straw consumption had been limited in these experiments with veal calves.

\section{Chemical Analysis}

The diet and digesta samples were analyzed as previously described (Guilloteau et al., 1986; Lallès and Poncet, 1990). Briefly, DM and ash were determined by drying in an oven at $105^{\circ} \mathrm{C}$ for $16 \mathrm{~h}$ and $600^{\circ} \mathrm{C}$, respectively. Chromium was extracted from ash residue and measured by atomic absorption spectrometry (PerkinElmer 2380 spectrometer). Nitrogen was measured using the Reardon method (Reardon et al., 1966) and data expressed on a CP basis using 6.25 as conversion factor.

\section{Determination of Protein/Peptide Molecular Mass Profiles in Diets and Digesta}

Sample preparation. Freeze-dried samples of feed and digesta were homogenized $(60 \mathrm{mg} / \mathrm{ml})$ in $40 \mathrm{mM}$ phosphate buffer, $\mathrm{pH} 7$, containing $1 \%$ SDS and $0.2 M$ 2-mercapto-ethanol. Total CP were then extracted by heating at $100^{\circ} \mathrm{C}$, for $20 \mathrm{~min}$. After cooling, extracts were centrifuged $(15 \mathrm{~min}, 24000 \times \mathrm{g}$ ) and supernatants were filtered (Minisart Sartorius Filter $0.20 \mu \mathrm{m}$, Goettingen, Germany). The filtrates were then frozen at $-20^{\circ} \mathrm{C}$ until chromatography fractionation.

Chromatography fractionation. Separation of proteins and peptides according to $M_{r}$ was carried out by gel filtration on a TSK PW precolumn and a TSK PW XL G3000 column measuring $30 \mathrm{~cm}$ length and $7.8 \mathrm{~mm}$ internal diameter (Tosa Hass, Montgomeryville, PA), as described previously (Crévieu et al., 1997b). Each filtrate (200 $\mu \mathrm{l}$ representing approximately $800 \mu \mathrm{g}$ of CP) was applied on the top of the column and eluted at a rate of $0.6 \mathrm{ml} / \mathrm{min}$ with $40 \mathrm{mM}$ phosphate buffer, $\mathrm{pH} \mathrm{7,} \mathrm{con-}$ 
taining $0.1 \%$ SDS. The void volume was determined with thyroglobulin $\left(M_{r}=330,000\right)$. The column was calibrated using BSA $\left(M_{r}=66,000\right)$, carbonic anhydrase $\left(M_{r}=\right.$ $29,000)$, cytochrom C $\left(M_{r}=12,400\right)$, insulin $\left(M_{r}=5750\right)$, and glucose $\left(M_{r}=180\right)$ as $M_{r}$ standards. All were purchased from Sigma (St Louis, MO). Six fractions were collected. Fraction 1 corresponded to proteins with a $M_{r}$ $>20,000$; fraction 2 to proteins with $20,000 \geq M_{r}>10,000$; fraction 3 to proteins or peptides with $10,000 \geq M_{r}>4500$; fraction 4 to peptides with $4500 \geq M_{r}>2000$; fraction 5 to peptides with $2000 \geq M_{r}>400$; and fraction 6 to oligopeptides and free AA with $M_{r} \leq 400$.

Analysis of protein and peptide fraction. A 150$\mu \mathrm{l}$ aliquot of each fraction was hydrolyzed with $50 \mu \mathrm{l}$ of $8 \mathrm{M} \mathrm{NaOH}$ for $2 \mathrm{~h}$ at $130^{\circ} \mathrm{C}$. Samples were then neutralized with $100 \mu \mathrm{l}$ of $40 \%$ acetic acid. Next, $\alpha$-amino nitrogen was estimated by reaction with o-phtaldialdehyde according to the method of Frister et al. (1988). A standard curve was prepared with graded concentrations of leucine ( 0 to $1 \mathrm{mM}$ ) and the results were expressed as $\mathrm{m} M$ of leucine equivalents according to Crévieu et al. (1997b).

\section{Expression of Results}

The concentration of $\alpha$-amino nitrogen in each fraction from a sample was multiplied by the volume of this fraction. Then, the percentage of $\mathrm{CP}\left(\% \mathrm{CP} \mathrm{F}_{\mathrm{i}}\right)$ in each fraction i was calculated as follows:

$$
\text { \% CP F } \mathrm{C}_{\mathrm{i}}=\alpha \text {-amino } \mathrm{NF}_{\mathrm{i}} / \sum_{\mathrm{i}=1}^{\mathrm{i}=6}\left(\alpha \text {-amino } \mathrm{N} \mathrm{F}_{\mathrm{i}}\right)
$$

where $\alpha$-amino $\mathrm{NF}_{\mathrm{i}}$ was the content of $\alpha$-amino nitrogen in the fraction $\mathrm{i}$ in $\mathrm{m} M$ equivalent leucine.

The flow of CP from each fraction in digesta was calculated using the following equations. First, the flow of digesta was calculated individually from the dilution factor of the indigestible marker as previously described (Montagne et al., 2001):

$$
\text { Flow of digesta }=\mathrm{Cr} \text { intake } / \mathrm{Cr}_{\text {digesta }}
$$

where the flow of digesta is in $\mathrm{kg} / \mathrm{d}, \mathrm{Cr}$ intake = the amount of $\mathrm{Cr}$ intake in $\mathrm{g} / \mathrm{d}$ and $\mathrm{Cr}_{\text {digesta }}=$ the $\mathrm{Cr}$ concentration in digesta in $\mathrm{g} / \mathrm{kg}$. The flow of DM and total CP was next calculated as follows:

$$
\begin{gathered}
\text { Flow of } \mathrm{DM}=\mathrm{DM}_{\text {digesta }} \times \text { Flow of digesta } \\
\text { Flow of } \mathrm{CP}=\text { Flow of } \mathrm{DM} \times \mathrm{CP}_{\text {digesta }}
\end{gathered}
$$

where the flow of DM and CP are in $\mathrm{g} / \mathrm{d}, \mathrm{DM}_{\text {digesta }}=$ concentration of $\mathrm{DM}$ in digesta in $\mathrm{g} / \mathrm{kg}$, flow of digesta is in $\mathrm{kg} / \mathrm{d}$, and $\mathrm{CP}_{\text {digesta }}=$ concentration of $\mathrm{CP}$ in digesta in $\mathrm{g} / \mathrm{g} \mathrm{DM}$.

The flow of CP was also calculated per kg DMI per d for comparison with literature data. Then, the flow of $\mathrm{CP}$ in each fraction (flow of $\mathrm{CP}$ in $\mathrm{F}_{\mathrm{i}}$ in $\mathrm{g} / \mathrm{kg} \mathrm{DMI} / \mathrm{d}$ ) was calculated by multiplying the flow of CP (in g/kg DMI/ d) by the percentage of $\mathrm{CP}$ in each fraction $\left(\% \mathrm{CP} \mathrm{F}_{\mathrm{i}}\right)$ as follows:

$$
\text { Flow of } \mathrm{CP} \text { in } \mathrm{F}_{\mathrm{i}}=\text { Flow of } \mathrm{CP} \times \% \mathrm{CP} \mathrm{F}_{\mathrm{i}}
$$

\section{Statistical Analysis}

As described previously (Montagne et al., 2001) data of flow from experiment 1 and individual trials of experiment 2 were analyzed as repeated measures for each calf-diet combination, at each intestinal site, using the Repeated statement of the general linear model procedure of SAS (SAS, 1990). Significant intestinal site effects were partitioned into single degrees of freedom orthogonal comparisons, i.e., into linear and quadratic effects of the distance of the cannula from the duodenum. When the effect of diet was significant, differences between means were separated by Bonferroni's test. Differences were declared significant at $P<0.05$.

\section{RESULTS}

\section{Distribution of Proteins and Peptides in Diets}

The distribution of proteins and peptides in the diets is shown in Table 2. In experiment 1, 55 to $60 \%$ of total CP of diets containing SMP had $M_{r}>20,000$ whereas less than $6 \%$ had $M_{r} \leq 400$. The protein-free diet contained only $14 \mathrm{~g} \mathrm{CP} / \mathrm{kg}$ DM because protein supplement was not included in the formula and so proteins came only from the milk cream as the source of fat. This diet contained less protein with $M_{r}>20,000$ (45.5\%) and more oligopeptides and free AA with $M_{r} \leq 400(18.4 \%)$ than the diets containing SMP.

In experiment 2, the control diet based on SMP and the diets containing soybean and potato concentrates had a similar protein and peptide distribution. They contained 64 to $68 \%$ of proteins with $M_{r}>20,000$ and less than $5 \%$ of oligopeptides and AA with $M_{r} \leq 400$. Distribution of CP in the HSPI diet differed from the other diets containing plant protein sources. It contained less proteins with $M_{r}>20,000$ (48\%) due to partial hydrolysis and, consequently, more proteins and peptides with $M_{r}<20,000$. The percentage of CP in fractions 2 to 6 was 46 to 59\% higher with HSPI than with the other diets used in experiment 2. 
Table 2. Distribution of protein and peptide fractions in diets according to $M_{r}$ (in \% of total CP).

\begin{tabular}{|c|c|c|c|c|c|c|c|c|c|}
\hline \multirow{2}{*}{\multicolumn{2}{|c|}{ Fraction $\mathrm{n}^{\circ}$ and $M_{r}$}} & \multicolumn{4}{|c|}{ Diets of experiment $1^{1}$} & \multicolumn{4}{|c|}{ Diets of experiment $2^{2}$} \\
\hline & & 14 & 104 & 205 & 279 & Control & SPC & HSPI & PPC \\
\hline 1 & $>20,000$ & 45.5 & 55.2 & 59.1 & 60.4 & 64.9 & 65.7 & 48.0 & 68.2 \\
\hline 2 & 20,000 to 10,000 & 11.9 & 14.7 & 17.3 & 11.7 & 9.4 & 9.8 & 13.8 & 8.6 \\
\hline 3 & 10,000 to 4500 & 6.6 & 8.9 & 8.1 & 6.9 & 6.5 & 6.1 & 9.8 & 5.9 \\
\hline 4 & 4500 to 2000 & 5.1 & 5.6 & 3.7 & 6.2 & 4.7 & 4.9 & 7.3 & 4.1 \\
\hline 5 & $2000-400$ & 12.5 & 9.7 & 6.9 & 10.2 & 8.5 & 8.5 & 13.2 & 8.0 \\
\hline 6 & $\leq 400$ & 18.4 & 5.9 & 4.9 & 4.6 & 6.0 & 5.0 & 7.9 & 5.1 \\
\hline
\end{tabular}

${ }^{1} \mathrm{CP}$ in $\mathrm{g} / \mathrm{kg} \mathrm{DM}$, diets containing milk cream alone $(14 \mathrm{~g} \mathrm{CP} / \mathrm{kg} \mathrm{DM})$ or mixed with increasing amounts of skim milk powder to obtain 104, 205, and $279 \mathrm{~g} \mathrm{CP} / \mathrm{kg} \mathrm{DM}$.

${ }^{2}$ Diets containing a mixture of skim milk powder and soybean protein concentrate (SPC), hydrolyzed soybean proteins isolate (HSPI), or potato protein concentrate (PPC) as protein sources.

\section{Distribution of Proteins and Peptides in Digesta}

Experiment 1. Figure 1 illustrates the differences in $M_{r}$ distribution of digesta CP between intestinal sites and according diets, in calves receiving diets varying in CP level. With the diets containing 14, 105, and 279 g CP/kg DM, fraction $1\left(M_{r}>20,000\right)$ at the jejunum represented a percentage higher, or similar to that at the duodenum. Conversely fractions 5 and $6\left(M_{r} \leq 2000\right)$ at the jejunum were inferior than or similar to that at the duodenum. By contrast, with the diet containing $205 \mathrm{~g} \mathrm{CP} / \mathrm{kg} \mathrm{DM}$, the contribution of proteins with $M_{r}>$

\section{a. $14 \mathrm{~g} \mathrm{CP} / \mathrm{kg}$ DM}

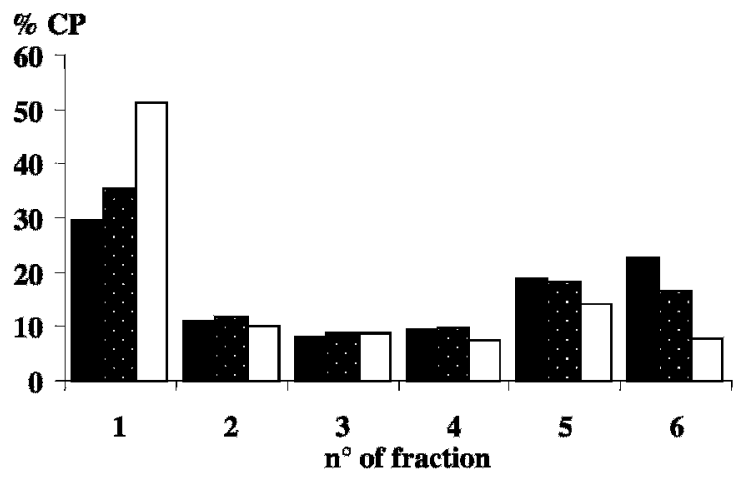

c. $205 \mathrm{~g} \mathrm{CP} / \mathrm{kg} \mathrm{DM}$

\% CP

60

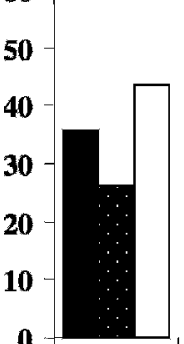

1

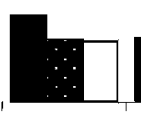

2

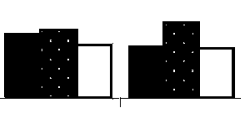

3

4

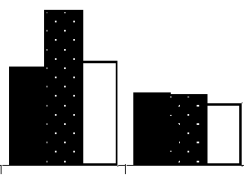

56 $n$ of fraction

b. $105 \mathrm{~g} \mathrm{CP} / \mathrm{kg} \mathrm{DM}$
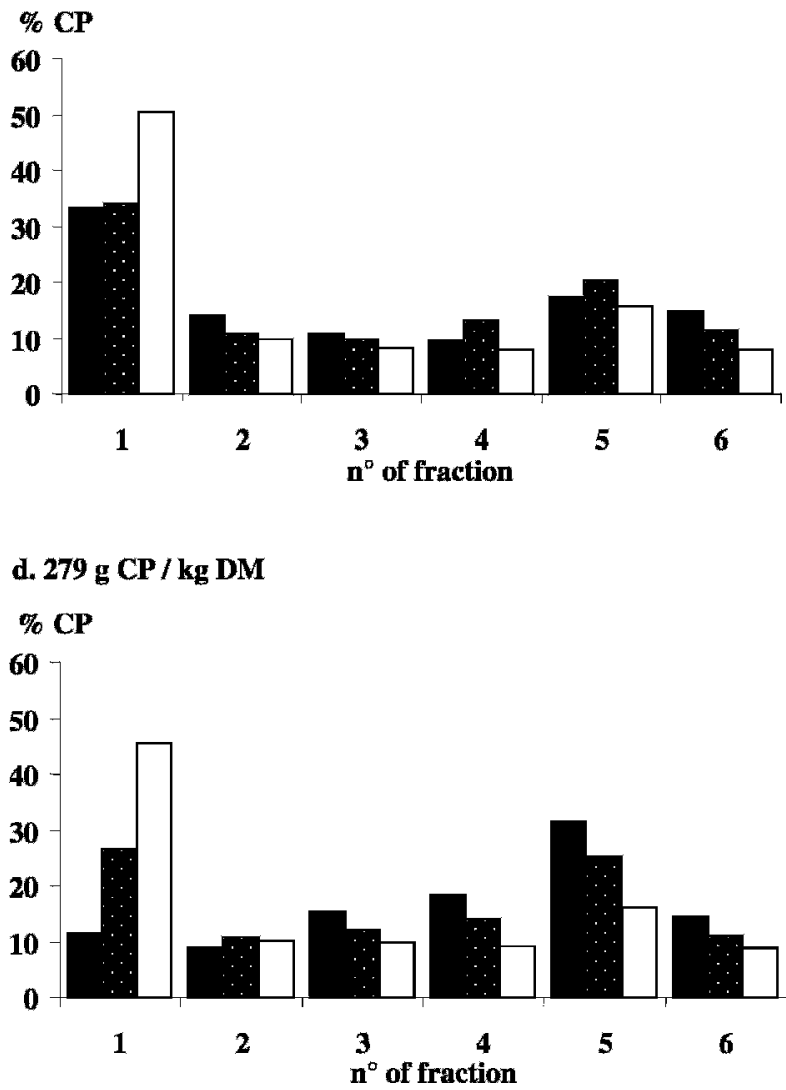

Figure 1. Effect of dietary CP content on the distribution of digesta CP according to molecular masses $\left(M_{r}\right)$ in $\%$ of total CP in digesta. Pooled digesta from calves fed diet containing: a) 14 g CP/kg DM; b) 104 g CP/kg DM; c) 205 g CP/kg DM, and d) 279 g CP/kg DM. Fraction 1: $M_{r}>20,000$; fraction 2: 20,000 $\geq M_{r}>10,000$; fraction 3: 10,000 $\geq M_{r}>4500$; fraction 4: $4500 \geq M_{r}>2000$; fraction 5: 2000 $\geq M_{r}>400$; fraction 6: $M_{r} \leq 400$. Solid bar: Duodenum, dotted bar: jejunum, open bar: ileum. 
Table 3. Effect of the dietary CP content on the flow and distribution of protein and peptide fractions according to $M_{r}$ along the small intestine of calves (g/kg DM/d).

\begin{tabular}{|c|c|c|c|c|c|c|c|c|}
\hline \multirow{2}{*}{\multicolumn{2}{|c|}{ Fraction $\mathrm{n}^{\circ}$ and $M_{r}$}} & \multirow[b]{2}{*}{ Site $^{1}$} & \multicolumn{4}{|c|}{ Diet (CP content in $\mathrm{g} / \mathrm{kg} \mathrm{DM})$} & \multirow[b]{2}{*}{ SEM } & \multirow[b]{2}{*}{$P_{\mathrm{d}}^{2}$} \\
\hline & & & 14 & 104 & 205 & 279 & & \\
\hline \multirow{3}{*}{\multicolumn{2}{|c|}{$>20.000$}} & $\mathrm{D}$ & $9.5^{\mathrm{D}}$ & $44.6^{\mathrm{B}}$ & $86.6^{\mathrm{A}}$ & $34.2^{\mathrm{C}}$ & 1.7 & 0.001 \\
\hline & & $\mathrm{J}$ & $11.7^{\mathrm{B}}$ & $31.0^{\mathrm{C}}$ & $39.2^{\mathrm{A}}$ & $51.2^{\mathrm{A}}$ & 4.0 & 0.001 \\
\hline & & I & 10.3 & 12.3 & 11.6 & 8.9 & 0.7 & 0.518 \\
\hline \multirow{3}{*}{\multicolumn{2}{|c|}{20,000 to 10,000}} & $\mathrm{D}$ & $3.5^{\mathrm{C}}$ & $18.7^{\mathrm{B}}$ & $36.3^{\mathrm{A}}$ & $26.5^{\mathrm{A}}$ & 0.8 & 0.001 \\
\hline & & $\mathrm{J}$ & $3.9^{\mathrm{C}}$ & $9.9^{\mathrm{B}}$ & $15.8^{\mathrm{AB}}$ & $20.7^{\mathrm{A}}$ & 1.5 & 0.001 \\
\hline & & I & 2.0 & 2.4 & 2.8 & 2.0 & 0.2 & 0.196 \\
\hline \multirow[t]{3}{*}{3} & 10,000 to 4500 & $\mathrm{D}$ & $2.6^{\mathrm{D}}$ & $14.5^{\mathrm{C}}$ & $27.1^{\mathrm{B}}$ & $46.1^{\mathrm{A}}$ & 0.8 & 0.001 \\
\hline & & $\mathrm{J}$ & $2.9^{\mathrm{C}}$ & $9.0^{\mathrm{B}}$ & $17.5^{\mathrm{AB}}$ & $23.6^{\mathrm{A}}$ & 1.7 & 0.001 \\
\hline & & I & 1.8 & 2.0 & 2.5 & 1.9 & 0.1 & 0.150 \\
\hline \multirow[t]{3}{*}{4} & 4500 to 2000 & $\mathrm{D}$ & $3.1^{\mathrm{D}}$ & $12.7^{\mathrm{C}}$ & $21.3^{\mathrm{B}}$ & $54.1^{\mathrm{A}}$ & 0.8 & 0.001 \\
\hline & & $J$ & $3.3^{\mathrm{C}}$ & $12.0^{\mathrm{B}}$ & $19.5^{\mathrm{AB}}$ & $27.1^{\mathrm{A}}$ & 1.9 & 0.001 \\
\hline & & I & 1.5 & 2.0 & 2.3 & 1.8 & 0.1 & 0.077 \\
\hline \multirow[t]{3}{*}{5} & 2000 to 400 & $\mathrm{D}$ & $6.1^{\mathrm{C}}$ & $23.2^{\mathrm{B}}$ & $40.7^{\mathrm{A}}$ & $93.7^{\mathrm{A}}$ & 1.4 & 0.001 \\
\hline & & $\mathrm{J}$ & $6.1^{\mathrm{C}}$ & $18.5^{\mathrm{B}}$ & $39.4^{\mathrm{A}}$ & $49.0^{\mathrm{A}}$ & 3.6 & 0.001 \\
\hline & & I & 2.9 & 3.8 & 4.7 & 3.2 & 0.2 & 0.070 \\
\hline \multirow{3}{*}{\multicolumn{2}{|c|}{$\leq 400$}} & $\mathrm{D}$ & $7.2^{\mathrm{D}}$ & $19.8^{\mathrm{C}}$ & $29.8^{\mathrm{B}}$ & $42.5^{\mathrm{A}}$ & 0.8 & 0.001 \\
\hline & & $J$ & $5.4^{\mathrm{C}}$ & $10.5^{\mathrm{B}}$ & $17.8^{\mathrm{AB}}$ & $21.9^{\mathrm{A}}$ & 1.7 & 0.001 \\
\hline & & I & $1.6^{\mathrm{B}}$ & $2.0^{\mathrm{AB}}$ & $2.7^{\mathrm{A}}$ & $1.8^{\mathrm{AB}}$ & 0.1 & 0.026 \\
\hline \multirow{3}{*}{\multicolumn{2}{|c|}{ Total }} & $\mathrm{D}$ & $32.2^{\mathrm{D}}$ & $133.4^{\mathrm{C}}$ & $242.0^{\mathrm{B}}$ & $297.4^{\mathrm{A}}$ & 6.0 & 0.001 \\
\hline & & $\mathrm{J}$ & $33.2^{\mathrm{C}}$ & $90.8^{\mathrm{BC}}$ & $149.2^{\mathrm{AB}}$ & $193.8^{\mathrm{A}}$ & 14.4 & 0.004 \\
\hline & & I & 20.0 & 24.5 & 26.5 & 19.5 & 1.5 & 0.213 \\
\hline
\end{tabular}

${ }^{1}$ Site within the small intestine: D duodenum, J jejunum, I ileum. The effect of the site was significant and linear $(P<0.0001)$ for all the fractions.

${ }^{2}$ Probability of a diet effect.

A,B,C,D Means $(\mathrm{n}=6)$ with different letters in a same row and for a given site were statistically different $(P<0.05)$.

20,000 was lower at the jejunum than at the duodenum, and that of fraction with $M_{r} \leq 2000$ was higher. Between the jejunum and ileum, the contribution of the fractions with $M_{r}>20,000$ increased, and that with $M_{r} \leq 2,000$ decreased, regardless of the dietary CP level.

The data for the flow of $\mathrm{CP}$ and distribution according to $M_{r}$ obtained in calves receiving diets varying in $\mathrm{CP}$ level are presented in Table 3. The flow of total CP and $\mathrm{CP}$ in each fraction decreased linearly along the small intestine $(P<0.0001)$. With the protein-free diet, the total flow of $\mathrm{CP}$ and the flow of $\mathrm{CP}$ in fractions with $M_{r}$ $>400$ were quite similar at the duodenum and jejunum. The flow of total CP decreased between the jejunum and the ileum by approximately $40 \%$. This was explained mainly by the decrease in the flow of CP from fractions 2 to $6\left(M_{r} \leq 20,000\right)$.

Increasing the dietary CP level affected the flow of total $\mathrm{CP}$ and that of $\mathrm{CP}$ in all fractions at the duodenum and jejunum. At the duodenum, the flow of fraction with $M_{r}>10,000$ was maximum with the diet containing 205 g CP/kg DM. The duodenal flow of other fractions and the flow of all the fractions at the jejunum were the highest with the diet containing $279 \mathrm{~g} \mathrm{CP} / \mathrm{kg} \mathrm{DM}$. At the ileum, the dietary CP level significantly increased the flow of oligopeptides and free AA only $\left(M_{r}<400\right.$; $+70 \%$ between diets containing 14 and $205 \mathrm{~g} \mathrm{CP} / \mathrm{kg} \mathrm{DM}$,
$P<0.05)$. The dietary CP level did not significantly affect the ileal flow of the other fractions.

Experiment 2. Figure 2 illustrates the differences in $M_{r}$ distribution of digesta CP between sites and diets in calves receiving diets differing in the protein source. The main observation was that the percentage of protein with a high $M_{r}$ (fraction 1) decreased between the duodenum and jejunum and then increased between the jejunum and ileum, regardless of the diet. Conversely, the proportion of peptides, oligopeptides and free AA (fractions 5 and 6 ) increased between the duodenum and the jejunum and decreased between the jejunum and the ileum.

The data for the flow of $\mathrm{CP}$ and distribution according to $M_{r}$ obtained in calves receiving diets varying in the protein source are presented in Table 4 . As observed in experiment 1 , the flow of total $\mathrm{CP}$ and $\mathrm{CP}$ in each fraction decreased along the small intestine $(P<0.0001)$. With the control diet, the total flow of CP was, on average for the three trials, 228, 67 , and $19 \mathrm{~g} / \mathrm{kg} \mathrm{DMI} / \mathrm{d}$, at the duodenum, jejunum and ileum, respectively. The flow of $\mathrm{CP}$ in fractions 1 to 6 was on average at the duodenum $79,39,28,22,36$, and $23 \mathrm{~g} / \mathrm{kg} \mathrm{DMI} / \mathrm{d}$, respectively, and at the jejunum $13,5.3,6.1,8.2,19.7$, and $14.1 \mathrm{~g} / \mathrm{kg}$ DMI/ $\mathrm{d}$, respectively. At the ileum, it was on average 8.0, 2.5, $1.8,1.7,5.3$, and $15.5 \mathrm{~g} / \mathrm{kg} \mathrm{DMI} / \mathrm{d}$. 

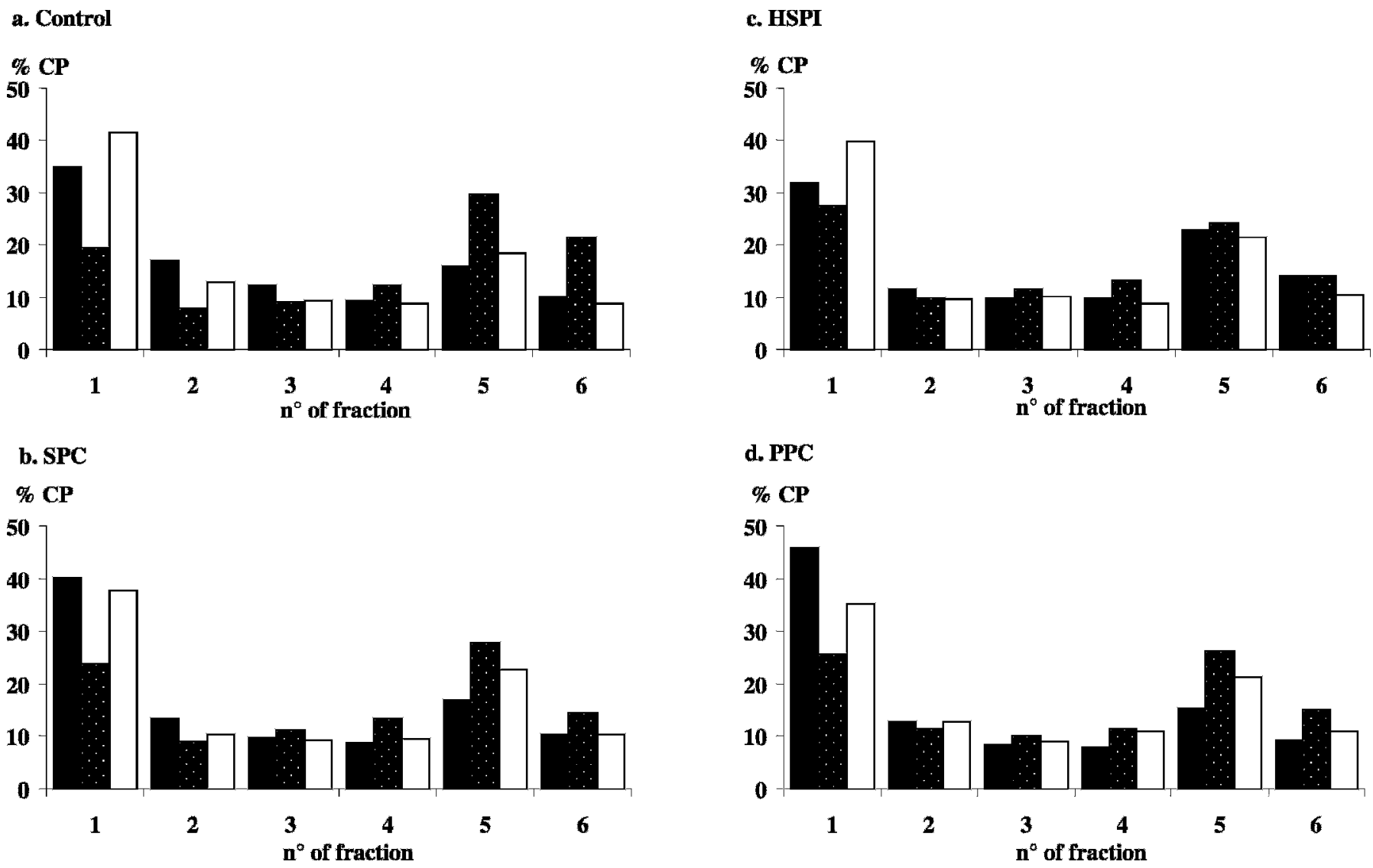

Figure 2. Effect of the nature of dietary CP on the distribution of digesta CP according to molecular masses $\left(M_{r}\right)$ in $\%$ of total CP in digesta. Pooled digesta from calves fed: a) the control diet based on skim milk powder; b) the diet containing the soybean protein concentrate (SPC); c) the diet containing the hydrolyzed soybean protein isolate (HSPI), and d) the diet containing the potato protein concentrate (PPC). Fraction 1: $M_{r}>20,000$; fraction 2: 20,000 $\geq M_{r}>10,000$; fraction 3: 10,000 $\geq M_{r}>4500$; fraction 4: $4500 \geq M_{r}>2000$; fraction 5: 2000 $\geq$ $M_{r}>$ 400; fraction 6: $M_{r} \leq 400$. Solid bar: Duodenum, dotted bar: jejunum, open bar: ileum.

Incorporating plant protein sources into milk replacers affected the flow of total $\mathrm{CP}$ and that of $\mathrm{CP}$ in each fraction at all sites of the small intestine. At the duodenum, the nature of protein did not affect the total flow of CP but it modified CP distribution into the $M_{r}$ fractions. In particular, the flow of protein from fractions 2 and $3\left(20,000 \geq M_{r}>4500\right)$ decreased when SMP was partially replaced by plant protein $(P<0.05$ for fraction 2 with HSPI and PPC diets and for fraction 3 with SPC and PPC diets). By contrast, the flow of peptides, oligopeptides and free $\mathrm{AA}\left(M_{r}<2000\right)$ increased when plant protein was incorporated into the milk replacers $(P<$ 0.06 for fraction 5 with the SPC and HSPI diets, and for fraction 6 with the HSPI and PPC diets).

The flow of total CP at the jejunum tended to be higher with plant proteins, as compared with the control diet $(+66 \%$ and $+40 \%$ with the SPC and PPC diets, respectively, $P<0.08$ ). This was, or tended to, hold true for the flow of each fraction.
The flow of total CP in ileal digesta was nearly doubled with diet SPC $(P=0.07)$, three-fold higher with HSPI $(P=0.06)$, and two-fold higher with PPC $(P<0.001)$ compared with the control diet. The flow of $\mathrm{CP}$ significantly increased in most fractions when SMP was partially replaced by plant protein, but the magnitude of this increase differed between fractions. Especially, the flow of CP in fractions of $M_{r}<2000$ increased more than in fraction of higher $M_{r}$ (fractions 1 and 2). This lead to an accumulation of peptides, oligopeptides, and free AA in ileal digesta of calves fed with plant proteins compared with SMP.

\section{DISCUSSION}

In most experiments published thus far concerning protein digestion in calves, attention was focused on the flow of total CP at the ileum only. Here, we proposed a more detailed study of protein digestion, by characteriz- 
Table 4. Effect of the source of dietary protein on the flow and distribution of protein and peptide fractions according to $\mathrm{M}_{\mathrm{r}}$ along the small intestine of the calves $(\mathrm{g} / \mathrm{kg} \mathrm{DM} / \mathrm{d})$.

\begin{tabular}{|c|c|c|c|c|c|c|c|c|c|c|c|c|c|c|}
\hline \multirow{2}{*}{\multicolumn{2}{|c|}{ Fraction $\mathrm{n}^{\circ}$ and $M_{r}$}} & \multirow[b]{2}{*}{ Site $^{1}$} & \multicolumn{4}{|c|}{ SPC trial } & \multicolumn{4}{|c|}{ HSPI trial } & \multicolumn{4}{|c|}{ PPC trial } \\
\hline & & & Control & $\mathrm{SPC}^{2}$ & SEM & $P_{\mathrm{d}}^{3}$ & Control & $\mathrm{HSPI}^{4}$ & SEM & $P_{\mathrm{d}}^{3}$ & Control & $\mathrm{PPC}^{5}$ & SEM & $P_{\mathrm{d}}^{3}$ \\
\hline \multirow{2}{*}{\multicolumn{2}{|c|}{$>20$}} & $\mathrm{D}$ & 64.4 & 114.1 & 2.4 & 0.002 & 77.5 & 71.8 & 2.9 & 0.184 & 95.9 & 100.6 & 2.2 & 1.000 \\
\hline & & I & 9.4 & 15.3 & 1.0 & 0.135 & 6.5 & 23.0 & 1.7 & 0.026 & 8.0 & 13.7 & 0.7 & 0.004 \\
\hline \multirow{3}{*}{\multicolumn{2}{|c|}{20,000 to 10,000}} & $\mathrm{D}$ & 42.1 & 38.2 & 0.8 & 1.000 & 39.0 & 26.2 & 1.1 & 0.038 & 36.2 & 28.3 & 0.7 & 0.006 \\
\hline & & $\mathrm{J}$ & 7.2 & 11.6 & 1.2 & 0.140 & 5.1 & 10.0 & 2.6 & 0.423 & 3.7 & 10.5 & 1.4 & 0.001 \\
\hline & & I & 2.5 & 4.3 & 0.3 & 0.034 & 3.0 & 5.5 & 0.4 & 0.096 & 2.0 & 5.0 & 0.3 & 0.001 \\
\hline & & I & 1.7 & 3.7 & 0.2 & 0.013 & 1.9 & 5.9 & 0.4 & 0.038 & 1.7 & 3.5 & 0.2 & 0.001 \\
\hline \multirow{3}{*}{\multicolumn{2}{|c|}{4500 to 2000}} & $\mathrm{D}$ & 22.8 & 24.6 & 0.5 & 0.374 & 21.4 & 22.6 & 0.9 & 1.000 & 20.5 & 17.3 & 0.4 & 0.020 \\
\hline & & $\mathrm{J}$ & 10.5 & 17.3 & 1.7 & 0.071 & 6.9 & 13.4 & 3.4 & 0.423 & 7.3 & 10.6 & 1.6 & 0.040 \\
\hline & & I & 1.7 & 3.9 & 0.3 & 0.006 & 1.7 & 5.0 & 0.4 & 0.039 & 1.7 & 4.2 & 0.2 & 0.001 \\
\hline \multirow{3}{*}{\multicolumn{2}{|c|}{2000 to 400}} & $\mathrm{D}$ & 37.1 & 48.1 & 1.0 & 0.034 & 38.5 & 51.5 & 2.0 & 0.057 & 33.7 & 33.7 & 0.7 & 1.000 \\
\hline & & $\mathrm{J}$ & 23.1 & 36.0 & 3.6 & 0.160 & 16.8 & 24.8 & 6.3 & 0.728 & 19.1 & 23.9 & 3.8 & 0.155 \\
\hline & & I & 3.7 & 9.2 & 0.6 & 0.011 & 4.1 & 12.3 & 0.9 & 0.039 & 2.9 & 8.2 & 0.4 & 0.001 \\
\hline \multirow{2}{*}{\multicolumn{2}{|c|}{ Total }} & $\mathrm{J}$ & 77.4 & 128.5 & 12.7 & 0.076 & 57.0 & 102.3 & 26.1 & 0.434 & 65.0 & 91.2 & 14.0 & 0.068 \\
\hline & & I & 20.6 & 40.7 & 2.7 & 0.065 & 19.3 & 57.7 & 4.3 & 0.056 & 17.7 & 38.8 & 2.0 & 0.001 \\
\hline
\end{tabular}

${ }^{1}$ Site within the small intestine: D duodenum, J jejunum, I ileum. The effect of the site was always significant and linear $(P<0.01)$.

${ }^{2}$ Diet containing soybean protein concentrate $(n=5)$.

${ }^{3}$ Probability of a diet effect.

${ }^{4}$ Diet containing hydrolyzed soybean protein isolate $(\mathrm{n}=3)$.

${ }^{5}$ Diet containing potato protein concentrate $(n=8)$.

ing the digesta $\mathrm{CP}$ in terms of molecular masses in the proximal duodenum, mid-jejunum and terminal ileum in veal calves.

\section{Effect of Dietary CP Level on Digestion of CP Along the Small Intestine}

Digesta from calves receiving the protein-free diet contained protein from endogenous origin only. The flow of proteins and peptides with $M_{r} \geq 400$ was globally similar at the duodenum and jejunum whereas it decreased between the jejunum and ileum. That of oligopeptides and free AA decreased along the small intestine.

At the duodenum, fraction $M_{r}>20,000$ probably contained endogenous proteins from digestive secretions, including enzymes and mucus, and proteins sloughedoff in the lumen from the lining of anterior segments of the gut, as suggested by Montagne et al. (2000) and Montagne et al. (2002). Endogenous proteins flowing at the duodenum are hydrolyzed and absorbed proximodistally by the same mechanisms as dietary proteins. In the present experiment, the similar flow of CP with $M_{r}$ $>20,000$ observed at the duodenum and jejunum could be explained by two phenomena. First, hydrolysis and absorption could be counterbalanced by secretion of other endogenous proteins, and second, proteins may be poorly hydrolyzed. Mucin especially has a high $M_{r}\left(M_{r}\right.$
$>10^{6}$ ) and a high degree of glycosylation that protects it from proteolysis. As an example, exhaustive in vitro proteolysis of mucin from the small intestine of pig resulted in a loss of $5 \%$ of the total mucin molecule only (Mantle et al., 1981).

At the ileum, the contribution of protein with $M_{r}>$ 20,000 was again high. It has recently been shown that mucin is a major contribution of ileal flow of CP (20\%; Montagne et al., 2000a). As mucin is a high $M_{r}$ glycoprotein, we suggest that it is the major component of fraction 1 with $M_{r}>20,000$. The remainder was probably proteins from the mucosa and from bacteria that colonize the terminal ileum.

When the dietary CP level increased, the flow of CP in all fractions increased at the duodenum and the jejunum. This could be easily explained by the presence of milk proteins in digesta. They have been shown to be mostly intact at the duodenum of calves fed diets containing SMP (Caugant et al., 1992), and so probably partially degraded at the jejunum. Our results confirmed that the digestion of proteins from SMP was not completed at the jejunum (Montagne et al., 2000b). At the ileum, the flow of CP with $M_{r}<400$ significantly increased with the dietary CP level. Oligopeptides and free AA represented on average $9 \%$ of total CP flowing at the ileum of calves fed the diet based on SMP. Accumulation of oligopeptides and free AA in ileal digesta was more pro- 
nounced in calves fed the diets based on SMP than the protein-free diet. Such an accumulation was also observed in other animal species. In pigs fed an enzymatically hydrolyzed casein, CP with $M_{r}<500$ represented 11 to $21 \%$ of the CP in ileal digesta (Moughan et al., 1990; Butts et al., 1992) whereas in chickens fed intact casein, this fraction accounted for $29 \%$ of total CP (Sklan and Hurwitz, 1980).

\section{Effect of Dietary Plant Protein Source on Digestion of CP along the Small Intestine}

The incorporation of plant protein into milk replacers for calves had no effect on the flow of total CP in duodenal digesta but it increased this flow at the jejunum and ileum. Moreover, $M_{r}$ distribution of CP was modified. The main effect was the accumulation of oligopeptides and free AA in ileal digesta. This was also observed in rats given severely heated protein (Zebrowska, 1968), and in chickens fed a diet containing pea protein (Crévieu et al., 1997a). A possible explanation is that the accumulation of undigested peptides saturated the absorption sites involved in the transport of $\mathrm{AA}$, di- and tri-peptides across the mucosal barrier, and so blocked AA uptake, as first hypothesized by Zebrowska (1968) from rat studies. Absorption of $\mathrm{AA}$, di- and tri-peptides might also be a limiting factor of plant protein digestion in the calf. This may explain why calves fed diets containing plant protein grow less than those fed SMP diets. In addition, it has been shown recently that protein catabolism in the muscle is higher when plant protein, as compared to SMP, is fed to pigs (Löhrke et al., 2001).

The origin of peptides accumulating in ileal digesta could be dietary or endogenous. Resistant dietary fractions have been evidenced in ileal digesta of calves fed soybean or potato proteins (Lallès et al., 1999; BrancoPardal et al., 1995), pigs fed kidney bean (Begbie and Ross, 1993) and chickens fed pea protein (Crévieu et al., 1997a). Dietary peptides might interact with the gut, and be responsible for the increase of endogenous secretion observed with plant protein (Montagne et al., 2001). This hypothesis is supported by the observation of Santoro et al. (1999) in rat fed pure phaseolin, the storage globulin of kidney bean Phaseolus vulgaris. Native phaseolin and/or related fragments that escaped digestion bound to the small intestinal epithelium. It was suggested that they could act as natural secretagogues stimulating secretion of endogenous protein, and especially mucin, from the mucosa (Santoro et al., 1999). The increase in the flow of proteins with $M_{r}>20,000$ in ileal digesta of calves fed diets containing plant protein, when compared with diets containing SMP, is in agreement with this hypothesis.
To conclude, partial replacement of SMP by plant protein sources lead to an accumulation of oligopeptides and free AA in ileal digesta of calves. Thus, the intestinal breakdown of oligopeptides and absorption may be a limiting step in the digestion process.

\section{ACKNOWLEDGMENTS}

The authors wish to thank S. Boussion, H. Flageul, G. Savary and P. Quinquis for assistance with the care of the calves and J. Quillet for gathering the literature. This work was supported in part by a grant (contract $n^{\circ}$ B00082) from the Région Bretagne, the Département d'Ille-et-Vilaine and the District de Rennes, to whom we are grateful.

\section{REFERENCES}

Asche, G. L., A. J. Lewis, and E. R. Peo. 1989. Protein digestion in weanling pigs: effects of feeding regimen and endogenous protein secretion. J. Nutr. 119:1083-1092.

Begbie, R., and A. W. Ross. 1993. Resistance of the kidney bean reserve protein, phasolein, to proteolysis in the porcine digestive tract. J. Sci. Food Agric. 61:301-307.

Branco-Pardal, P., J. P. Lallès, M. Formal, P. Guilloteau, and R. Toullec. 1995. Digestion of wheat gluten and potato protein by the preruminant calf: digestibility, amino acid composition and immunoreactive proteins in ileal digesta. Reprod. Nutr. Dev. 35:639-654.

Bush, R. S., R. Toullec, I. Caugant, and P. Guilloteau. 1992. Effects of raw pea flour on nutrient digestibility and immune responses in the preruminant calf. J. Dairy Sci. 75:3539-3552.

Butts, C. A., P. J. Moughan, and W. C. Smith. 1991. Endogenous amino acid flow at the terminal ileum of rat determined under conditions of peptide alimentation. J. Sci. Food Agric. 55:175-187.

Caugant, I., M. Yvon, S. Thirouin, H. Petit, R. Toullec, C. Bard, and L. Savoie. 1992. Characterization of products from in vivo and in vitro gastric digestion of milk replacers containing whey proteins. J. Sci. Food Agric. 40:1367-1374.

Crévieu, I., B. Carré, A. M. Chagneau,. L. Quillien, J Guéguen, and S. Bérot. 1997a. Identification of resistant pea (Pisum sativum L.) proteins in the digestive tract of chickens. J. Agric. Food Chem. 45:1295-1300.

Crévieu, I., B. Carré, J. Guéguen, J. P. Melcion, and A. M. Chagneau. 1997b. Effect of particle size of pea (Pisum sativum) flours on the digestion of their proteins in the digestive tract of broilers. J. Sci. Food Agric. 75:217-226.

Frister, H., H. Meisel, and E. Schlimme. 1988. OPA method modified by use of n,n-di-methyl-2-mercapthoethylammonium chloride as thiol component. Fresenius Zeitung Anal. Chem. 330:631-633.

Guilloteau, P., R. Toullec, J. F. Grongnet, P. Patureau-Mirand, J. Prugnaud, and D. Sauvant. 1986. Digestion of milk, fish and soyabean protein in the preruminant calf: flow of digesta, apparent digestibility at the end of the ileum and amino acid composition of ileal digesta. Br. J. Nutr. 55:571-592.

Lallès, J. P. 1993. Nutritional and antinutritional aspects of soyabean and field pea proteins used in veal calf production. A review. Livest. Prod. Sci. 34:181-202.

Lallès, J. P., and C. Poncet. 1990. Changes in ruminal and intestinal digestion during and after weaning in dairy calves fed high concentrate diets containing pea or soyabean meal 1- Digestion of organic matter and nitrogen. Livest. Prod. Sci. 24:129-142.

Lallès, J. P., R. Toullec, P. Branco Pardal, and J. W. Sissons. 1995. Hydrolyzed soy protein isolate sustains high nutritional performance in veal calves. J. Dairy Sci. 78:194-204.

Lallès, J. P., H. M. Tukur, P. Salgado, E. N. C. Mills, M. R. A. Morgan, L. Quillien, D. Levieux, and R. Toullec. 1999. Immunochemical 
studies on gastric and intestinal digestion of soybean glycinin and beta-conglycinin in vivo. J. Agric. Food Chem. 47:2797-2806.

Lallès, J. P., H. M. Tukur, R. Toullec, and B. G. Miller. 1996. Analytical criteria for predicting apparent digestibility of soybean protein in preruminant calves. J. Dairy Sci. 79:475-484.

Leterme, P., T. Monmart, A. Théwis, and P. Morandi. 1996. Effect of oral and parenteral $\mathrm{N}$ nutrition vs $\mathrm{N}$-free nutrition on the endogenous amino acid flow at the ileum of the pig. J. Sci. Food Agric. $71: 265-271$.

Löhrke, B., E. Saggau, R. Schadereit, M. Beyer, O. Bellmann, S. Kuhla, and H. Hagemeister. 2001. Activation of skeletal muscle protein breakdown following consumption of soyabean protein in pigs. $\mathrm{Br}$. J. Nutr. 85:447-457.

Longenbach, J. I., and A. J. A. Heinrichs. 1998. Review of the importance and physiological role of curd formation in the abomasum of young calves. Anim. Feed Sci. Tech. 73:85-97.

Mantle, M., D. Mantle, and A. Allen. 1981. Polymeric structure of pig small intestinal mucus glycoprotein. Biochem. J. 195:277-285.

Montagne, L., P. Salgado, R. Toullec, and J. P. Lallès. 2002. Effect of the dietary protein source on the activities of some enzymes in the small intestine mucosa and in digesta. J. Sci. Food Agric. In press.

Montagne, L., R. Toullec, M. Formal, and J. P. Lallès. 2000a. Influence of dietary protein level and origin on the flow of mucin along the small intestine of the preruminant calf. J. Dairy Sci. 83:2820-2828.

Montagne, L., R. Toullec, and J. P. Lallès. 2000b. Quantitative and qualitative changes in endogenous nitrogen components along the small intestine of the calf. J. Sci. Food Agric. 80:2123-2134.

Montagne, L., R. Toullec, and J. P. Lallès. 2001. Intestinal digestion of dietary and endogenous proteins along the small intestine of calves fed soybean or potato protein. J. Anim. Sci. 79:2719-2730.
Montagne, L., R. Toullec, T. C. Savidge, and J. P. Lallès. 1999. Influence of protein source and antigenicity of soyabean on morphology and enzyme activities of the proximal jejunum in preruminant calf. Reprod. Nutr. Dev. 39:80-81.

Moughan, P. J., A. J. Darragh, W. C. Smith, and C. A. Butts. 1990 Perchloric and trichloroacetic acids as precipitants of protein in endogenous ileal digesta from the rat. J. Sci. Food Agric. 52:13-21.

Nielsen, S. S., S. S. Deshpande, M. A. Hermodson, and M. P. Scott. 1988. Comparative digestibility of legume storage proteins. J. Agric. Food Chem. 36:896-902.

Reardon, J., J. A. Foreman, and R. L. Searcy. 1966. New reactants for the colorimetric quantitation of ammonia. Clin. Chim. Acta. 14:403-405.

Santoro, L. G., G. Grant, and A. Pusztai. 1999. In vivo degradation and stimulating effect of phaseolin on nitrogen secretion in rats. Plant Food Hum. Nutr. 53:223-236.

SAS User's Guide: Statistics, Version 6.0 Edition. 1990. SAS Inst., Inc., Cary, NC.

Sklan, D., and S. Hurwitz. 1980. Protein digestion in young chicks and turkeys. J. Nutr. 110:139-144.

Toullec, R., J. F. Frantzen, and C. M. Mathieu. 1974. Influence de la coagulation des protéines du lait sur l'utilisation digestive d'un lait de remplacement chez le veau préruminant. Ann. Zootech. 23:359-364

Toullec, R., and J. P. Lallès. 1995. Digestion dans la caillette et l'intestin grêle. Pages 527-581 in Nutrition des ruminants domestiques: ingestion et digestion; R. Jarrige, Y. Ruckebush, C. Demarquilly, M. H. Farce, and M. Journet, ed., INRA, Paris, France.

Zebrowska, T. 1968. The course of digestion of different food proteins in the rat. Fractionation of the nitrogen in intestinal contents. Br. J. Nutr. 22:483-491. 